\title{
Positive Role of Magnetic Separation Within Processing of Sideritized Bauxites of Kazakhstan
}

\author{
Viktor M. Sizyakov*, \\ Oleg A. Dubovikov and Denis A. Loginov \\ National Mineral Resources University of Mines \\ 2, 21st line, St. Petersburg, 199106, Russia
}

Received 29.03.2015, received in revised form 16.04.2015, accepted 24.05.2015

Big amount of research has been carried out in relation to high-silicon bauxites in recent years aimed at identifying methods of raw materials benefication, improving the combined sequential Bayersintering method and developing the new method for the hydrometallurgical processing [1-3]. One option of the bauxite chemical benefication is desiliconization by alkaline solution of bauxite subjected to preliminary thermal activation. Experimental data on the leaching of initial and calcined bauxite by recycle solution indicates that the preroasting of high-siderite bauxites enables to use Bayer process with better technological parameters [4]. Roasting improves the condensability of red mud, however, considering that the operation of roasting is associated with large energy costs, alternative technological scheme of low-quality gibbsite bauxites processing from various deposits of Kazakhstan has been proposed and tested in the laboratory and pilot scale.

Keywords: high-silicon bauxite, magnetic separation, decomposition degree, benefication, roasting.

\section{Положительная роль магнитной сепарации}

\section{при переработке}

\section{сидеритизированных бокситов Казахстана}

В.М. Сизяков, О.А. Дубовиков, Д.А. Логинов Национальный минерально-сырьевой университет «Горный» Россия, 199106, Санкт-Петербург, 21-я линия, 2

За последние годы применительно к высококремнистым бокситам выполнено большое количество работ, направленных на изыскание методов обогащения сырья, усовериенствование комбинированного последовательного способа Байер-спекания и разработку нового гидрометаллургического метода их переработки. Одним из вариантов химического обогащения бокситов является обескремнивание щелочным раствором боксита, прошедшего

(c) Siberian Federal University. All rights reserved

* Corresponding author E-mail address: kafmetall@mail.ru 
предварительную термическую активацию. Опытные данные по выщелачиванию исходного и обожженного боксита оборотным раствором указывают на то, что предварительный обжиг высокосидеритизированных бокситов позволит перерабатывать их по способу Байера с лучшими технологическими показателями. Обжиг способствует улучшению и сгущаемости красного шлама. Однако, учитывая, что операция обжига связана с большими энергозатратами, была предложена и проверена в лабораторном и опытно-промышленном маситабе альтернативная технологическая схема переработки низкокачественных гиббситовых бокситов различных месторождений Казахстана.

Ключевые слова: высококремнистые бокситы, магнитная сепарация, степень разложения, обогащчение, обжиг.

\section{Laboratory testing of the bauxite two-stage leaching technology with preliminary magnetic separation}

Technology includes ore grinding on mother liquor, pulp separation in strong magnetic field and processing of non-magnetic fraction by using sequential Bayer - sintering method. Magnetic fraction processing is recommended to carry out either in a separate branch or by sintering together with red mud. Technology of alumina extraction from non-magnetic fraction corresponds with the existing one at the Pavlodar aluminum plant.

The study was conducted on a sample of bauxite from Ayatskoye deposit consisting mainly of gibbsite with a considerable admixture of heavily damaged fine kaolinite and a very small admixture of boehmite. There is big amount of iron-containing minerals: hematite and siderite. Goethite is present in small quantities. Quartz and anatase are observed. Chemical composition [5] is shown in Table 1.

For modeling plant conditions of bauxite grinding on the mother liquor ones acted as follows. Initially, the dry bauxite was milled to the desired particle size, then it was stirred for $20 \mathrm{~min}$ with the mother liquor $\left(\mathrm{Na}_{2} \mathrm{O}_{\mathrm{k}}=140 \mathrm{~g} / 1\right.$ and $\left.\alpha_{\mathrm{k}}=3,5\right)$ at $45^{\circ} \mathrm{C}$ and the weight ratio of $\mathrm{L}: \mathrm{S}=1,5$. Next, the pulp was separated on polygradient separator SE-208. The magnetic product was preroasted at $500 \div 600{ }^{\circ} \mathrm{C}$ and time from 2 to $60 \mathrm{~min}$ and then leached at a temperature of $260{ }^{\circ} \mathrm{C}$ by aluminate solution of composition: $260 \mathrm{~g} / 1-\mathrm{Na}_{2} \mathrm{O}_{\mathrm{k}} ; 10 \mathrm{~g} / 1-\mathrm{Na}_{2} \mathrm{O}_{\text {carbon dioxide }} ; \alpha_{\mathrm{k}}=3,5$. Non-magnetic product was leached by aluminate solution with the same composition at $105^{\circ} \mathrm{C}$. This was followed by dilution of the pulp, desiliconization with duration of $4 \div 8 \mathrm{~h}$ at $105^{\circ} \mathrm{C}$ and condensability in the presence of the coagulant.

To compare the results a standard leaching of original bauxite was carried out at $105^{\circ} \mathrm{C}$ for two hours.

Table 1. Chemical composition of bauxite from Ayatskoye deposit

\begin{tabular}{|l|c|c|c|c|c|c|c|c|}
\hline \multirow{2}{*}{ Fraction, mm } & \multicolumn{9}{|c|}{ Content, \% } & \multirow{2}{*}{$\mu_{\mathrm{Si}}$} \\
\cline { 2 - 10 } & Ignition loss & $\mathrm{Al}_{2} \mathrm{O}_{3}$ & $\mathrm{SiO}_{2}$ & $\mathrm{Fe}_{2} \mathrm{O}_{3}$ & $\mathrm{FeO}$ & $\mathrm{CaO}$ & $\mathrm{CO}_{2}$ & \\
\hline$-1,00+0,50$ & 24,56 & 42,10 & 9,31 & 19,15 & 3,02 & 0,88 & 2,11 & 4,52 \\
\hline$-0,50+0,25$ & 23,48 & 41,57 & 12,30 & 18,47 & 2,30 & 0,81 & 2,00 & 3,38 \\
\hline$-0,25+0,16$ & 23,12 & 41,64 & 13,60 & 17,27 & 1,72 & 0,84 & 2,11 & 3,06 \\
\hline$-0,16+0,04$ & 21,82 & 40,00 & 14,00 & 18,64 & 1,65 & 1,18 & 2,00 & 2,86 \\
\hline$-0,04$ & 22,50 & 40,70 & 13,72 & 18,30 & 1,80 & 0,96 & 2,11 & 2,97 \\
\hline$\sum$ & 23,42 & 41,00 & 11,23 & 18,40 & 2,47 & 0,72 & 2,10 & 3,65 \\
\hline
\end{tabular}


Results presented in Table 2 show that the optimal particle size should be considered as grinding fineness $0,5 \mathrm{~mm}$ and current strength in the coils of magnetic separator $\sim 0,8 \mathrm{~A}$. Under these conditions at least $65-70 \%$ of carbon dioxide contained in the original bauxite can be converted to the magnetic fraction from bauxite repulped in the mother liquor when a ratio of $L: S=1,5: 1$. Siderite decomposition

Table 2. Effect of bauxite fineness on the performance of magnetic separation

\begin{tabular}{|c|c|c|c|c|c|c|c|c|c|c|c|}
\hline \multirow{2}{*}{$\begin{array}{c}\text { Fraction, } \\
\text { current } \\
\text { strength }(\mathrm{A})\end{array}$} & \multirow{2}{*}{$\begin{array}{c}\text { Output, } \\
\%\end{array}$} & \multicolumn{7}{|c|}{ Content, $\%$} & \multicolumn{3}{|c|}{ Extraction, \% } \\
\hline & & $\begin{array}{l}\text { Ignition } \\
\text { loss }\end{array}$ & $\mathrm{Al}_{2} \mathrm{O}_{3}$ & $\mathrm{SiO}_{2}$ & $\mathrm{Fe}_{2} \mathrm{O}_{3}$ & $\mathrm{FeO}$ & $\mathrm{CaO}$ & $\mathrm{CO}_{2}$ & $\mathrm{CO}_{2}$ & $\mathrm{Fe}_{2} \mathrm{O}_{3}$ & $\mathrm{Al}_{2} \mathrm{O}_{3}$ \\
\hline \multicolumn{12}{|c|}{ Separation on water of bauxite with fineness $2 \mathrm{~mm}$} \\
\hline 0,4 & 14,0 & & & & & & & 2,57 & 17,1 & & \\
\hline 0,8 & 23,4 & & & & & & & 3,05 & 34,0 & & \\
\hline 1,0 & 10,4 & & & & & & & 1,96 & 9,7 & & \\
\hline Non-magnetic & 52,2 & 23,86 & 42,34 & 13,0 & 15,39 & 1,20 & 0,90 & 1,49 & 38,9 & 42,5 & 55,2 \\
\hline 3,0 & 46,0 & & & & 24,60 & & & 3,88 & 84,8 & 57,8 & \\
\hline 6,0 & 15,0 & & & & 21,55 & & & 1,29 & 9,0 & 14,2 & \\
\hline Non-magnetic & 39,0 & 24,26 & 44,80 & 13,6 & 14,00 & 0,60 & 0,90 & 0,36 & 6,2 & 29,0 & 43,7 \\
\hline \multicolumn{12}{|c|}{ Separation on mother liquor of bauxite with fineness $2,00 \mathrm{~mm}$} \\
\hline 0,4 & 12,3 & & & & 28,73 & & & 4,43 & 26,9 & 24,6 & \\
\hline 0,8 & 34,9 & & & & 30,27 & & & 2,39 & 39,9 & 41,8 & \\
\hline 1,0 & 5,8 & & & & 20,00 & & & 1,91 & 6,2 & 6,1 & \\
\hline Non-magnetic & 47,0 & & 42,51 & & 12,80 & & & 1,16 & 25,9 & 31,8 & 49,9 \\
\hline 3,0 & 46,5 & & & & & & & 3,09 & 68,4 & 69,9 & \\
\hline 6,0 & 9,7 & & & & & & & 1,50 & 6,9 & & \\
\hline Non-magnetic & 43,8 & 28,86 & 43,22 & 14,2 & 10,60 & 0,50 & 0,96 & 1,10 & 22,9 & 28,5 & 47,4 \\
\hline \multicolumn{12}{|c|}{ Separation on mother liquor of bauxite with fineness $1,00 \mathrm{~mm}$} \\
\hline 0,4 & 8,3 & & & & 29,41 & & & 5,73 & 22,8 & 12,9 & \\
\hline 0,8 & 8,3 & & & & 28,41 & & & 4,73 & 21,8 & 12,9 & \\
\hline 1,0 & 7,7 & & & & & & & 5,06 & 21,2 & & \\
\hline Non-magnetic & 75,7 & & 42,34 & & 13,53 & & & 0,95 & 34,2 & 54,1 & 80,0 \\
\hline 3,0 & 28,4 & & & & 33,50 & & & 3,60 & 48,6 & 50,3 & \\
\hline 6,0 & 21,4 & & & & 19,15 & & & 1,08 & 11,0 & 19,6 & \\
\hline Non-magnetic & 50,2 & 23,88 & 43,68 & 13,9 & 11,46 & 0,62 & 1,10 & 1,30 & 40,6 & 30,4 & 54,8 \\
\hline \multicolumn{12}{|c|}{ Separation on mother liquor of bauxite with fineness $0,50 \mathrm{~mm}$} \\
\hline 0,4 & 6,2 & & & & 35,57 & & & 8,72 & 25,7 & 14,4 & \\
\hline 0,8 & 5,3 & & & & 31,12 & & & 10,26 & 25,8 & 8,5 & \\
\hline 1,0 & 6,3 & & & & 41,72 & & & 8,70 & 26,1 & 13,9 & \\
\hline Non-magnetic & 82,2 & & 42,83 & & 14,50 & & & 0,53 & 20,7 & 63,0 & 88,0 \\
\hline 3,0 & 12,1 & & & & 32,83 & & & 5,20 & 29,9 & 21,0 & \\
\hline 6,0 & 13,8 & & & & 37,29 & & & 4,98 & 32,7 & 27,2 & \\
\hline Non-magnetic & 74,1 & 23,7 & 43,15 & 13,9 & 12,70 & 0,43 & 0,88 & 1,05 & 37,0 & 49,7 & 79,9 \\
\hline \multicolumn{12}{|c|}{ Separation on mother liquor of bauxite with fineness $0,25 \mathrm{~mm}$} \\
\hline 0,4 & 4,2 & & & & 33,52 & & & 5,93 & 20,5 & 10,1 & \\
\hline 0,8 & 3,8 & & & & 28,04 & & & 2,96 & 9,6 & 5,9 & \\
\hline 1,0 & 4,0 & & & & 35,28 & & & 2,90 & 10,5 & 7,4 & \\
\hline Non-magnetic & 88,0 & & 41,49 & & 16,00 & & & 1,20 & 56,2 & 74,5 & 91,3 \\
\hline 3,0 & 4,2 & & & & 41,90 & & & 5,37 & 10,7 & 10,3 & \\
\hline 6,0 & 16,3 & & & & 28,70 & & & 1,84 & 14,3 & 25,7 & \\
\hline Nonmagnetic & 79,5 & & 42,5 & & 15,37 & & & 1,89 & 74,5 & 64,6 & 84,5 \\
\hline
\end{tabular}


Table 3. Effect of roasting conditions on the composition of cinder

\begin{tabular}{|c|c|c|c|c|c|}
\hline \multicolumn{2}{|c|}{ Roasting conditions } & \multicolumn{3}{|c|}{ Cinder } & \multirow{3}{*}{$\begin{array}{c}\text { Extraction } \\
\mathrm{CO}_{2}, \%\end{array}$} \\
\hline \multirow{2}{*}{ Temperature } & \multirow{2}{*}{ Duration,min } & \multirow{2}{*}{ Output, $\%$} & \multicolumn{2}{|c|}{ Content, $\%$} & \\
\hline & & & $\mathrm{CO}_{2}$ & $\mathrm{Fe}_{2} \mathrm{O}_{3}$ & \\
\hline \multirow{5}{*}{$500^{\circ} \mathrm{C}$} & 10 & 96,0 & 1,35 & 29,41 & 45,4 \\
\hline & 20 & 92,5 & 1,10 & 30,28 & 53,7 \\
\hline & 30 & 96,0 & 1,10 & 31,12 & 53,9 \\
\hline & 40 & 96,0 & 1,00 & 34,54 & 58,1 \\
\hline & 60 & 96,0 & 1,08 & 35,06 & 54,7 \\
\hline \multirow{5}{*}{$550^{\circ} \mathrm{C}$} & 5 & 85,0 & 0,89 & 30,37 & 59,3 \\
\hline & 10 & 88,4 & 0,81 & 29,73 & 64,3 \\
\hline & 15 & 88,1 & 0,63 & 31,03 & 71,2 \\
\hline & 20 & 88,0 & 0,52 & 32,34 & 76,2 \\
\hline & 30 & 88,1 & 0,48 & 30,78 & 78,1 \\
\hline \multirow{4}{*}{$600^{\circ} \mathrm{C}$} & 2 & 90,0 & 2,25 & 32,49 & 3,6 \\
\hline & 10 & 80,0 & 0,70 & 39,50 & 73,4 \\
\hline & 15 & 79,0 & 0,50 & 40,36 & 81,2 \\
\hline & 30 & 79,0 & 0,53 & 38,31 & 81,2 \\
\hline
\end{tabular}

Table 4. Effect of leaching conditions on the alumina extraction

\begin{tabular}{|c|c|c|c|c|c|c|c|}
\hline \multirow{2}{*}{$\begin{array}{l}\text { Fineness, } \\
\mathrm{mm}\end{array}$} & \multirow{2}{*}{ L:S Ratio } & \multirow{2}{*}{$\begin{array}{l}\text { Time, } \\
\text { min. }\end{array}$} & \multicolumn{4}{|c|}{ Mud from leaching } & \multirow{2}{*}{$\begin{array}{l}\text { Extraction } \\
\mathrm{Al}_{2} \mathrm{O}_{3}, \%\end{array}$} \\
\hline & & & Output, \% & $\mathrm{Al}_{2} \mathrm{O}_{3}, \%$ & $\mathrm{Fe}_{2} \mathrm{O}_{3}, \%$ & $\mathrm{Na}_{2} \mathrm{O}, \%$ & \\
\hline \multirow{2}{*}{0,5} & $5: 1$ & $\begin{array}{l}30 \\
60\end{array}$ & $\begin{array}{l}59,0 \\
66,5\end{array}$ & $\begin{array}{l}12,13 \\
12,31\end{array}$ & $\begin{array}{l}53,82 \\
54,92\end{array}$ & $\begin{array}{l}8,93 \\
8,96\end{array}$ & $\begin{array}{l}82,11 \\
79,54\end{array}$ \\
\hline & $9: 1$ & $\begin{array}{l}20 \\
60\end{array}$ & $\begin{array}{l}64,0 \\
61,5\end{array}$ & $\begin{array}{l}12,45 \\
11,42\end{array}$ & $\begin{array}{l}59,00 \\
54,82\end{array}$ & $\begin{array}{l}9,59 \\
8,40\end{array}$ & $\begin{array}{l}80,10 \\
82,50\end{array}$ \\
\hline \multirow{2}{*}{1,0} & $5: 1$ & $\begin{array}{l}30 \\
60 \\
\end{array}$ & $\begin{array}{l}52,0 \\
50,0\end{array}$ & $\begin{array}{l}12,38 \\
12,19\end{array}$ & $\begin{array}{l}53,54 \\
54,82\end{array}$ & $\begin{array}{l}8,80 \\
8,56\end{array}$ & $\begin{array}{l}83,91 \\
84,80\end{array}$ \\
\hline & $9: 1$ & $\begin{array}{l}30 \\
40\end{array}$ & $\begin{array}{l}66,0 \\
65,0\end{array}$ & $\begin{array}{l}11,78 \\
11,42\end{array}$ & $\begin{array}{l}52,89 \\
54,83\end{array}$ & $\begin{array}{l}8,40 \\
8,00\end{array}$ & $\begin{array}{l}80,57 \\
81,45\end{array}$ \\
\hline
\end{tabular}

degree does not exceed $10 \div 15 \%$. Output of magnetic fraction is not more than $20 \%$, when the content in the non-magnetic fraction, \%: 0,53 $\mathrm{CO}_{2} ; 42-43 \mathrm{Al}_{2} \mathrm{O}_{3}$ and $14-15 \mathrm{SiO}_{2}$.

When bauxite roasting carbonates are fast enough and almost completely decomposed. The optimal roasting conditions have been determined by studies: temperature $550 \div 600{ }^{\circ} \mathrm{C}$ and duration 15-20 min (Table 3). The carbon dioxide content is reduced to $0,5 \%$, which corresponds to $\sim 80 \%$ of $\mathrm{CO}_{2}$ conversion into the gas phase. The remaining amount of carbon dioxide is associated with calcite.

Leaching of cinder by recycle solution within 30 min allows to convert $80-83 \%$ of aluminum oxide contained in the magnetic fraction into the solution (Table 4), although silicon module of cinder 4.5-5.0.

Reason for the high extraction of $\mathrm{Al}_{2} \mathrm{O}_{3}$ from cinder lies in physical and chemical transformations of aluminosilicates during roasting. 


\section{Pilot-scale testing of the bauxite two-stage leaching technology with preliminary magnetic separation}

Technological scheme of processing of bauxites from Krasnooktyabrskoye deposit has been proposed based on laboratory testing and program of semi-industrial test on Pavlodar aluminum plant has been developed.

Technological scheme (Fig. 1) of semi-industrial tests included the following operations:

1) Bauxite grinding;

2) Magnetic separation;

3) Leaching of non-magnetic fraction by recycle solution;

4) Dilution and desiliconization of aluminate solution;

5) Condensability and triple washing of red mud.

Drum filter separator SE-248 designed by institute "Mekhanobr" has been used for the pulp separation. According to the results of previous tests performed on bauxite sample from Ayatskoye deposit and additional developmental testing of mode during debugging of technological scheme the following parameters of magnetic separation have been adopted: the current in the separator coil winding - $25 \mathrm{~A}$; speed of cells $-0,147 \mathrm{~m} / \mathrm{s}$; water consumption per magnetic product flush $-4,6 \mathrm{~m} / \mathrm{h}$.

Output of separation product was determined from conditions:

$$
\gamma_{M}+\gamma_{H}=100
$$

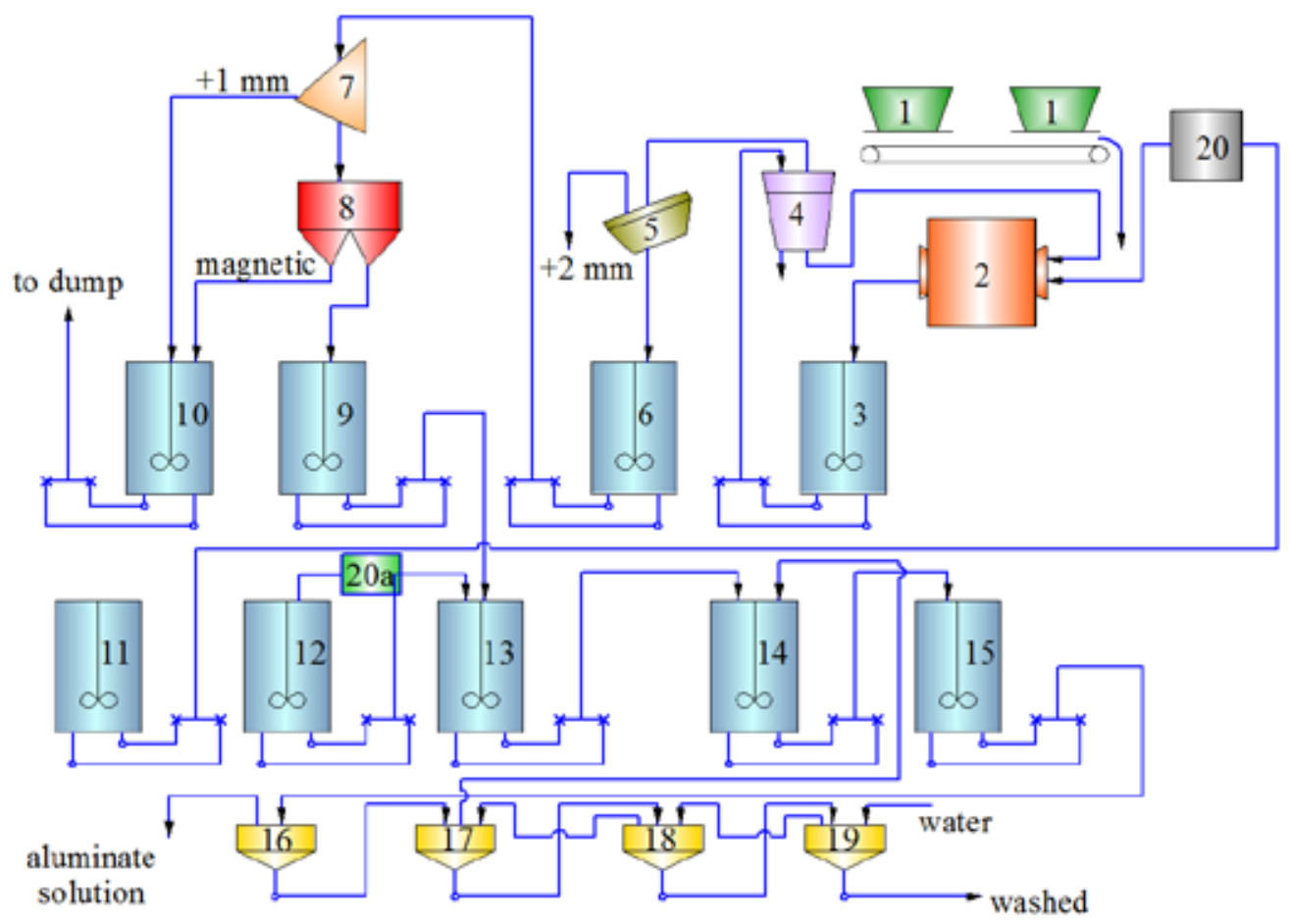

Fig. 1. Circuit diagram of processing apparatus of bauxites from Kazakhstan deposites with magnetic separation: 1 - hoppers for crushed bauxite, 2 - ball mill, 6, 9-15 - agitators, 4 - hydrocyclone $\varnothing 250 \mathrm{~mm}, 5$ - opening sieve with a gap $2 \mathrm{~mm}, 7$ - sieve with a gap $1 \mathrm{~mm}, 8$ - magnetic filter separator SE-248, 16-19 - one-level settlers, 20 - float feeder 


$$
\frac{\tilde{a}_{i} \cdot \hat{a}_{i}}{\dot{a}}+\frac{\tilde{a}_{i} \cdot \hat{a}_{i}}{\dot{a}}=100 \rightarrow \tilde{a}_{i}=\frac{100\left(\dot{a}-\hat{a}_{i}\right)}{\hat{a}_{i}-\hat{a}_{i}},
$$

where $\tilde{a}_{i}$ - output of magnetic product, $\% ; \hat{a}_{i}-$ content in the magnetic product, $\% ; \tilde{a}_{i}-$ output of non-magnetic product, $\% ; \hat{a}_{i}-$ content in the non-magnetic product, $\% ; \dot{a}-$ content in the original bauxite.

According to the performance of the technological scheme shown in Table 5 the calculation of indicators of enrichment has been presented, results are shown in Tables 6 and 7, which implies that the degree of siderite decomposition for the period is $33,9 \%$ per amount of $\mathrm{CO}_{2}$ in the original bauxites.

The siderite decomposition degree was determined by the difference $100 \%$ minus $\mathrm{CO}_{2} \%$ extraction into the magnetic product and minus $\mathrm{CO}_{2} \%$ extraction into the non-magnetic product. The outputs of the magnetic and non-magnetic products were determined by the iron content in the products. This magnitude doesn't correspond with soda increase in mother liquor after magnetic separation.

Furthermore, $\mathrm{CO}_{2}$ content is determined as $4.63 \%$ in average sample formed over the whole test period. This was the basis for clarification of methods of enrichment product outputs calculating and distribution of carbon dioxide in products. Calculation of separation products outputs can be carried

Table 5. Results of magnetic separation of bauxite on the mother liquor

\begin{tabular}{|c|c|c|c|c|c|c|c|c|}
\hline \multirow[t]{2}{*}{ Product } & \multirow{2}{*}{$\begin{array}{c}\text { Output } \\
\%\end{array}$} & \multicolumn{6}{|c|}{$\begin{array}{l}\text { Content in product, \% } \\
\text { (Extraction into product, \%) }\end{array}$} & \multirow[t]{2}{*}{$\mu_{\mathrm{Si}}$} \\
\hline & & $\mathrm{Al}_{2} \mathrm{O}_{3}$ & $\mathrm{TiO}_{2}$ & $\mathrm{SiO}_{2}$ & $\mathrm{Fe}_{2} \mathrm{O}_{3}$ & $\mathrm{CO}_{2}{ }^{*}$ & $\mathrm{CaO}$ & \\
\hline Magnetic & 22,5 & $\frac{29,1}{(15,3)}$ & $\frac{6,25}{(---)}$ & $\stackrel{---}{(16,7)}$ & $\frac{32,7}{(43,5)}$ & $\frac{8,78}{(60,8 / 40,2)^{* *}}$ & $\frac{2,47}{38,3}$ & 4,66 \\
\hline Non-magnetic & 77,5 & $\frac{46.7}{(84,7)}$ & $\frac{9,06}{(---)}$ & $\frac{---}{(83,3)}$ & $\frac{12,3}{(56,5)}$ & $\frac{1,64}{(39,2 / 25,9)^{* *}}$ & $\frac{1,16}{(61,7)}$ & 5,13 \\
\hline Separator feeding & 100,0 & $\frac{42,7}{(100)}$ & $\frac{8,43}{(---)}$ & $\frac{---}{(100)}$ & $\frac{16,9}{(100)}$ & $\frac{3,25}{(100 / 69,9) * *}$ & $\frac{1,45}{(100)}$ & 5,06 \\
\hline
\end{tabular}

* Content in the original bauxite $\mathrm{CO}_{2}=4,92 \%$.

** (Extraction from operation / from original bauxite).

Table 6. Average chemical composition of magnetic separation products

\begin{tabular}{|c|c|c|c|c|c|c|c|c|c|}
\hline \multirow{2}{*}{ Product } & \multicolumn{9}{|c|}{ Content in solid phase, $\%$} \\
\hline & Ignition loss & $\mathrm{Al}_{2} \mathrm{O}_{3}$ & \multicolumn{2}{|c|}{\begin{tabular}{l|l}
$\mathrm{SiO}_{2}$ & \\
\end{tabular}} & $\mathrm{TiO}_{2}$ & $\mathrm{CaO}$ & $\mathrm{Fe}_{2} \mathrm{O}_{3}$ & $\mathrm{FeO}$ & $\mathrm{CO}_{2}$ \\
\hline Bauxite & 26,79 & 42,75 & \multicolumn{2}{|c|}{9,75} & 1,89 & 1,30 & 15,46 & 7,75 & 4,64 \\
\hline Magnetic & 25,69 & 29,18 & \multicolumn{2}{|c|}{6,13} & 1,50 & 2,49 & 32,35 & 16,16 & 8,74 \\
\hline Non-magnetic & 27,21 & 47,00 & \multicolumn{2}{|c|}{8,89} & 2,00 & 1,05 & 4,51 & 3,34 & 1,61 \\
\hline \multirow{2}{*}{ Product } & \multicolumn{9}{|c|}{ Concentration of liquid phase, $\mathrm{g} / \mathrm{dm}^{-3}$} \\
\hline & \multicolumn{2}{|l|}{$\mathrm{Al}_{2} \mathrm{O}_{3}$} & $\mathrm{Na}_{2} \mathrm{O}_{\text {com }}$ & \multicolumn{2}{|c|}{$\mathrm{Na}_{2} \mathrm{O}_{\mathrm{k}}$} & $\mathrm{Na}_{2} \mathrm{O}_{\text {car. diox. }}$ & & $\alpha_{\text {com }}$ & $\alpha_{\mathrm{K}}$ \\
\hline Non-magnetic & \multicolumn{2}{|l|}{61,0} & 131,2 & \multicolumn{2}{|c|}{105,2} & 26,0 & \multicolumn{2}{|c|}{3,54} & 2,84 \\
\hline Mother liquor & 66,5 & \multicolumn{2}{|c|}{146,8} & \multicolumn{2}{|l|}{126,1} & 20,7 & \multicolumn{2}{|c|}{3,63} & 3,12 \\
\hline
\end{tabular}

Note: The performance of the mill on natural bauxite $2,05 \mathrm{t} / \mathrm{h}$, the mother liquor flow $2,24 \mathrm{~m}^{3} / \mathrm{t}$ of bauxite 
Viktor M. Sizyakov, Oleg A. Dubovikov... Positive Role of Magnetic Separation Within Processing of Sideritized Bauxites...

Table 7. Calculated values of separation product outputs

\begin{tabular}{|l|c|c|c|c|c|}
\hline \multirow{2}{*}{ Product } & \multicolumn{3}{|c|}{ Elements on which the output are calculated, \% } & \multirow{2}{*}{ Mean, \% } \\
\cline { 2 - 6 } & $\mathrm{TiO}_{2}$ & $\mathrm{CaO}$ & $\mathrm{Fe}_{2} \mathrm{O}_{3}$ & $\mathrm{Al}_{2} \mathrm{O}_{3}$ & \\
\hline Magnetic & 22,0 & 17,5 & 18,9 & 23,8 & 20,5 \\
\hline Non-magnetic & 78,0 & 82,5 & 81,1 & 76,2 & 79,5 \\
\hline
\end{tabular}

Table 8. Dependence of carbonates extraction by enrichment products on the content in the original bauxite

\begin{tabular}{|c|c|c|c|}
\hline $\begin{array}{c}\text { Content } \\
\text { in the bauxite, } \%\end{array}$ & Product & $\mathrm{CO}_{2}$ Extraction, \% & Notes \\
\hline 4,30 & $\begin{array}{l}\text { Magnetic } \\
\text { Non-magnetic }\end{array}$ & $\begin{array}{l}41,66 \\
29,76\end{array}$ & $\begin{array}{l}\text { When calculating the average } \mathrm{CO}_{2} \text { content in the } \\
\text { bauxite results of all analyses have been considered }\end{array}$ \\
\hline 4,64 & $\begin{array}{l}\text { Magnetic } \\
\text { Non-magnetic }\end{array}$ & $\begin{array}{l}38,66 \\
27,58\end{array}$ & Analyses over $2 \% \mathrm{CO}_{2}$ have been considered \\
\hline 5,09 & $\begin{array}{l}\text { Magnetic } \\
\text { Non-magnetic }\end{array}$ & $\begin{array}{l}35,20 \\
25,14\end{array}$ & Analyses over $4 \% \mathrm{CO}_{2}$ have been considered \\
\hline
\end{tabular}

out on any of the non-dissolving elements. Table 7 shows that when calculating the output of the magnetic product on element concentrated in it (calcium, iron) a smaller value is obtained than when calculation on element concentrated in the non-magnetic fraction (titanium, aluminum). This is due to losses of bauxite in the form of mill shingle and opening sieve big particles.

For further calculations, the average values have been taken: magnetic product output $20,5 \%$, output of non-magnetic product $79,5 \%$.

Table 8 shows the magnitude of $\mathrm{CO}_{2}$ extraction into the product of enrichment depending on the content in the original bauxite since the results of bauxite analysis have considerable variation (from $1,97 \%$ to $6 \%$ ).

According to the data, noticeable amount of iron is lost during preparation process: part with mill shingle and a part in the form of oversize product by drain filtration of hydrocyclone through opening sieve with a gap of $2 \mathrm{~mm}$. In view of the fact that carbon dioxide represented by siderite will be lost along with iron, the degree of siderite decomposition on the ore preparation stage during the test is more trustworthy defined by growth of soda in the mother liquor rather than by difference between the content in the original bauxite and the content of separation products in the solid phase. When the ratio of bauxite in the slurry and mother liquor $2,25 \mathrm{~m}^{3} / \mathrm{t}$ of moist bauxite and bauxite moisture $11,2 \%$,

$$
(26,0-20,7) \cdot(146,8 / 131,2) \cdot(44 / 62)=4,2 \mathrm{~kg}
$$

dissolve in $1 \mathrm{~m}^{3}$ of the liquid phase of the pulp entering the magnetic separation.

Therefore, $(1,0 \cdot 0,112+2,25) \cdot 4,2=9,92 \mathrm{~kg}$ of carbon dioxide dissolve during the enrichment of 1 ton of bauxite of moisture $11,2 \%$.

Accordingly, the degree of siderite decomposition is $25,9 \%$ when $\mathrm{CO}_{2}$ content in the bauxite is $4,3 \%$ to; the degree of siderite decomposition is $24,0 \%$ when the content of $\mathrm{CO}_{2}$ is $4,64 \%$; and the degree of siderite decomposition is $21,9 \%$ when the content of $\mathrm{CO}_{2}$ is $5,08 \%$. About $10 \%$ of magnetic

$$
-425-
$$


product is trapped by the solid phase of the initial flow of the mother liquor, therefore, $10 \%$ of soda formed during interaction with the mother liquor siderite also go into magnetic product. Distribution of carbonates on enrichment products is shown in Table 9.

Condensability test results of magnetic product in vitro are presented in Table 10.

Filtration experience of not condensed and magnetic products in nutsch filter with the solids concentration $-70 \mathrm{~g} / 1$ and trough volume of $7 \mathrm{~m}^{3}$ has shown that for the first time $24 \%$ of the liquid is filtered, for the second time - only $18 \%$.

Clay layer was formed after two hours of filtering on sediment surface and filtering was carried out very slowly. Cake with $38 \%$ moisture was obtained only after six hours after filtration start. The program included condensability of non-magnetic product, but it did not occurred in the shop conditions, and nonmagnetic product was pumped to leaching tank from separator.

Evaluating the test results on the ore preparation stage, the following key points should be noted:

1. Mill capacity on bauxite during grinding on the mother liquor is lower than during grinding on the recycle liquor due to lack of ore dispersion because of gibbsite dissolving in recycle liquor.

2. Siderite concentrates in circulating load during grinding in a closed cycle millhydrocyclone.

3. Siderite decomposition (\%) has been determined of $34 \%$ at the stage of ore preparation when the output of the magnetic product is $22,5 \%$ and determining of this value by the difference $100 \%$ minus $\mathrm{CO}_{2}$ extraction in magnetic product and minus $\mathrm{CO}_{2}$ extraction in non-magnetic product. Systematic negative residual has been installed during balance calculations on the distribution of $\mathrm{CO}_{2}$

Table 9. Balance and distribution of carbonates on enrichment products

\begin{tabular}{|c|c|c|c|c|c|c|c|c|}
\hline \multirow{3}{*}{$\begin{array}{c}\% \mathrm{CO}_{2} \\
\text { In bauxite }\end{array}$} & \multicolumn{3}{|c|}{ Magnetic product } & \multicolumn{3}{|c|}{ Non-magnetic product } & \multirow{3}{*}{$\begin{array}{c}\text { Decompo- } \\
\text { sition } \\
\text { degree, } \%\end{array}$} & \multirow{3}{*}{$\begin{array}{c}\text { Residual, } \\
\%\end{array}$} \\
\hline & \multicolumn{2}{|c|}{ Phase } & \multirow{2}{*}{$\Sigma$} & \multicolumn{2}{|c|}{ Phase } & \multirow{2}{*}{$\sum$} & & \\
\hline & Solid & Liquid & & Solid & Liquid & & & \\
\hline 4,30 & 41,66 & 2,59 & 44,25 & 29,76 & 23,31 & 53,07 & 25,9 & $-2,68$ \\
\hline 4,64 & 38,61 & 2,40 & 41,01 & 27,58 & 21,60 & 49,18 & 24,0 & $-9,81$ \\
\hline 5,09 & 35,20 & 2,19 & 37,39 & 25,14 & 19,71 & 44,85 & 21,9 & $-17,20$ \\
\hline $5,00^{*}$ & 57,32 & 1,78 & 59,10 & 24,70 & 16,20 & 40,30 & 17,8 & 0,00 \\
\hline
\end{tabular}

* Calculation is made from conditions of bauxite processing containing $5 \%$ of $\mathrm{CO}_{2}$ with obtaining of $1,54 \%$ of $\mathrm{CO}_{2}$ in nonmagnetic product and increase of soda content in the mother liquor from $13,8 \%$ to $18,8 \%$ instead of $19,8 \%$ occurred.

Table 10. Comparative condensability results of magnetic product

\begin{tabular}{|l|c|c|c|c|c|c|c|c|}
\hline \multirow{2}{*}{ Product } & \multicolumn{7}{|c|}{ Condensed layer height $(\mathrm{mm})$ at the time (min) } \\
\cline { 2 - 8 } & 0 & 5 & 8 & 11 & 14 & 17 & 22 & 32 \\
\hline $\begin{array}{l}\text { Bauxite red mud, \%: } \\
43,2-\mathrm{Al}_{2} \mathrm{O}_{3} ; \text { 9,5- } \mathrm{SiO}_{2} ; 20,6-\mathrm{Fe}_{2} \mathrm{O}_{3}\end{array}$ & 24,5 & 19,0 & 18,7 & 17,7 & 15,0 & 14,5 & 13,5 & 13,0 \\
\hline $\begin{array}{l}\text { Magnetic product } \\
61,8 \mathrm{~g} \text { (solid)/dm }\end{array}$ & 23,5 & 22,3 & 21,2 & 19,8 & 18,8 & 17,5 & 16,0 & 15,0 \\
\hline $\begin{array}{l}\text { Magnetic product } \\
66,7 \mathrm{~g} \text { (solid)/dm }\end{array}$ & 23,8 & 23,0 & 22,1 & 21,2 & 20,5 & 19,2 & 18,1 & 17,0 \\
\hline
\end{tabular}


at the stage of ore preparation. It has pointed to a substantial loss of siderite with mill shingle and screen oversized material of hydrocyclone drain cleaning from big particles and higher reliability of siderite decomposition degree calculating by the growth of soda in the mother liquor at the stage of ore preparation. Calculated siderite decomposition in this way was $21,9 \div 25,9 \%$ for the reporting period.

4. Principle possibility of magnetic fraction dehydration by condensability and filtration has shown by studies. At the same time it has been found that the non-magnetic product is not condensed.

Alumina from a non-magnetic product - bauxite, from which siderite was removed, was leached in a flow-through tank with valuable agitator. The temperature was maintained by heating steam. Leaching was carried out under the following conditions: temperature $108{ }^{\circ} \mathrm{C}$; duration $-4,1$ hours. Dosage of recycle solution was $2,73 \mathrm{~m}^{3}$ per 1 ton of dry non-magnetic product. After boiling, the pulp was diluted by strong rinsing water to concentration of $120 \div 130 \mathrm{~g} / 1$ of $\mathrm{Na}_{2} \mathrm{O}_{\mathrm{k}}$, it was heated in a agitator at a temperature of $103{ }^{\circ} \mathrm{C}$ for $4,2 \mathrm{~h}$ in order to desiliconize aluminate solution, and it was pumped into the system of 4 thickeners with volume of $120 \mathrm{~m}^{3}$ and $8 \mathrm{~m}$ in diameter each. Aluminate solution was separated and red mud was thickened in the first unit. Three subsequent units served to wash it. Water containing not more than $0,2 \div 0,3 \mathrm{~g} / 1$ of $\mathrm{Na}_{2} \mathrm{O}_{\mathrm{k}}$ was used for washing.

The average compositions of the products on which alumina extraction indicators are calculated during non-magnetic product leaching, condensability and washing of red mud have been determined on the basis of experimental data for the reporting period. The average daily alumina extraction performance from non-magnetic product in the leaching process (Table 11) and the average results of hydrochemical stage of non-magnetic product processing for the reporting period (Table 12) are presented below.

Material indicates that the operation was carried out extremely unstably, alumina subextraction

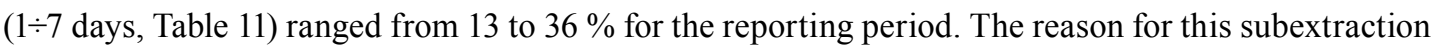
was low caustic concentration in recycle solution $\left(232 \div 255 \mathrm{~g} / 1 \mathrm{Na}_{2} \mathrm{O}_{\mathrm{k}}\right)$ and coarse grinding of bauxite, residue on the grid of $0,15 \mathrm{~mm}$ reached $27 \%$ instead of $5 \%$ given.

There has been improvement in the leaching during increase of alkali concentration in the recycle solution, and the process was carried out satisfactorily by the end of the reporting period. Because of the unstable flow, stable data on sieve composition of hydrocyclone drain has not been received for the test period.

In the period $(8 \div 10$ days, Table 11) alumina was close to the theoretical extraction in the leaching step, alumina subextraction ranged from 0 to $5,53 \%$ and averaged $2,3 \%$.

Evaluating the results of non-magnetic product processing, the following should be noted:

1. $\mathrm{Al}_{2} \mathrm{O}_{3}$ extraction during non-magnetic product leaching is close to the theoretically possible. The reason of subextraction is the presence of alumogoetite and chamosite in the original ore.

2. Aluminate solution desiliconization proceeds satisfactorily (silicon module $\sim 250$ ).

3. Drain linear velocity during the red mud sedimentation is $0,177 \mathrm{~m} / \mathrm{h}$ at $\mathrm{L}: \mathrm{S}$ of 2,5 in thickened red mud and removal of solid with drain $0,3 \div 0,4 \mathrm{~g} / \mathrm{l}$.

4. Good compactibility of red mud in washing system.

5. Incomplete carbon dioxide transition into solution is due to indecomposition of manganocalcite and oligonite.

6. Specific removal during filtration of red mud was $175,4 \mathrm{~kg} / \mathrm{m}^{2} \cdot \mathrm{h}$ on dry material with cake moisture of $40 \%$. 
Table 11. Indicators of non-magnetic product leaching

\begin{tabular}{|c|c|c|c|c|c|c|c|c|}
\hline \multirow{2}{*}{ Days } & \multirow{2}{*}{ Product } & \multicolumn{4}{|c|}{ Composition, $\%$} & \multirow{2}{*}{ Output } & \multirow{2}{*}{ Extraction, \% } & \multirow{2}{*}{ Subextraction, $\%$} \\
\hline & & $\mathrm{Al}_{2} \mathrm{O}_{3}$ & $\mathrm{SiO}_{2}$ & $\mathrm{Fe}_{2} \mathrm{O}_{3}$ & $\mathrm{Na}_{2} \mathrm{O}$ & & & \\
\hline \multirow{2}{*}{1} & \multirow{2}{*}{$\begin{array}{l}\text { Non-magnetic } \\
\text { Boiled pulp }\end{array}$} & 42,26 & 9,15 & 12,15 & & \multirow{2}{*}{52,16} & \multirow{2}{*}{65,45} & \multirow{2}{*}{12,95} \\
\hline & & 27,99 & 19,28 & 23,29 & 4,75 & & & \\
\hline \multirow{2}{*}{2} & \multirow{2}{*}{$\begin{array}{l}\text { Non-magnetic } \\
\text { Boiled pulp }\end{array}$} & 47,24 & 9,74 & 12,15 & & \multirow{2}{*}{72,71} & \multirow{2}{*}{42,95} & \multirow{2}{*}{36,43} \\
\hline & & 37,11 & 14,41 & 16,71 & & & & \\
\hline \multirow[b]{2}{*}{3} & \multirow{2}{*}{$\begin{array}{l}\text { Non-magnetic } \\
\text { Boiled pulp }\end{array}$} & 45,34 & 10,58 & 8,61 & & \multirow{2}{*}{49,88} & \multirow{2}{*}{60,69} & \multirow{2}{*}{15,72} \\
\hline & & 35,73 & 15,31 & 17,26 & 3,50 & & & \\
\hline \multirow{2}{*}{4} & \multirow{2}{*}{$\begin{array}{l}\text { Non-magnetic } \\
\text { Boiled pulp }\end{array}$} & 42,40 & 9,00 & 12,40 & & \multirow{2}{*}{58,49} & \multirow{2}{*}{54,75} & \multirow{2}{*}{24,01} \\
\hline & & 32,80 & 16,60 & 21,20 & 4,15 & & & \\
\hline \multirow{2}{*}{5} & \multirow{2}{*}{$\begin{array}{l}\text { Non-magnetic } \\
\text { Boiled pulp }\end{array}$} & 47,12 & 9,72 & 14,29 & & \multirow{2}{*}{59,54} & \multirow{2}{*}{66,03} & \multirow{2}{*}{13,30} \\
\hline & & 26,88 & 19,55 & 24,00 & & & & \\
\hline \multirow{2}{*}{6} & \multirow{2}{*}{$\begin{array}{l}\text { Non-magnetic } \\
\text { Boiled pulp }\end{array}$} & 47,60 & 9,06 & 11,60 & & \multirow{2}{*}{51,83} & & \\
\hline & & 23,65 & 18,39 & 22,38 & 4,70 & & 74,44 & 6,29 \\
\hline 7 & Non-magnetic & 47,24 & 9,11 & 11,69 & & & & \\
\hline 7 & Boiled pulp & 27,17 & 18,99 & 22,80 & 4,55 & 52,19 & 69,98 & 10,71 \\
\hline & Non-magnetic & 46,81 & 9,13 & 11,90 & & & & \\
\hline 8 & Boiled pulp & 22,08 & 20,14 & 28,80 & 5,35 & 41,31 & 80,51 & 0,00 \\
\hline 0 & Non-magnetic & 45,90 & 9,68 & 12,49 & & 5456 & & \\
\hline 9 & Boiled pulp & 22,40 & 20,98 & 26,40 & & 54,56 & 73,37 & 5,53 \\
\hline 10 & Non-magnetic & 46,54 & 9,09 & 12,80 & & 4444 & 7801 & 152 \\
\hline 10 & Boiled pulp & 22,08 & 20,75 & 28,80 & & 44,44 & 18,91 & 1,52 \\
\hline
\end{tabular}

Table 12. Average of non-magnetic product processing in the Bayer process

\begin{tabular}{|c|c|c|c|c|c|c|c|c|c|c|}
\hline \multirow[b]{2}{*}{ Product } & \multicolumn{10}{|c|}{ Solid phase content, $\%$} \\
\hline & $\begin{array}{c}\text { Ignition } \\
\text { loss }\end{array}$ & $\mathrm{Al}_{2} \mathrm{O}_{3}$ & \multicolumn{2}{|c|}{$\mathrm{SiO}_{2}$} & \multicolumn{2}{|c|}{$\mathrm{Fe}_{2} \mathrm{O}_{3}$} & $\mathrm{FeO}$ & $\mathrm{TiO}_{2}$ & $\mathrm{CaO}$ & $\mathrm{Na}_{2} \mathrm{O}$ \\
\hline Boiled pulp & 15,62 & 28,81 & \multicolumn{2}{|c|}{17,87} & \multicolumn{2}{|c|}{22,50} & & 3,78 & 1,84 & 3,74 \\
\hline Thickener charge pulp & 14,82 & 29,37 & \multicolumn{2}{|c|}{16,62} & \multicolumn{2}{|c|}{21,86} & 7,28 & 3,58 & 1,68 & 5,61 \\
\hline Thickener mud & 15,46 & 32,58 & \multicolumn{2}{|c|}{14,61} & \multicolumn{2}{|c|}{20,20} & & 3,20 & 1,36 & 6,19 \\
\hline \multirow[t]{2}{*}{ Washer mud } & 15,81 & 34,12 & \multicolumn{2}{|c|}{14,94} & \multicolumn{2}{|c|}{21,08} & & 3,22 & 1,38 & 6,33 \\
\hline & \multicolumn{10}{|c|}{ Content in the liquid phase, $\mathrm{g} / \mathrm{dm}^{3}$} \\
\hline Product & $\mathrm{Al}_{2} \mathrm{O}_{3}$ & \multicolumn{2}{|c|}{$\mathrm{Na}_{2} \mathrm{O}_{\text {com }}$} & \multicolumn{2}{|c|}{$\mathrm{Na}_{2} \mathrm{O}_{\mathrm{k}}$} & \multicolumn{2}{|c|}{$\alpha_{\text {com }}$} & $\alpha_{\mathrm{k}}$ & \multicolumn{2}{|c|}{ Solid } \\
\hline Boiled pulp & 138,9 & \multicolumn{2}{|c|}{174,80} & \multicolumn{2}{|c|}{143,38} & \multicolumn{2}{|c|}{2,07} & 1,69 & \\
\hline Thickener charge pulp & 118,4 & \multicolumn{2}{|c|}{154,70} & \multicolumn{2}{|c|}{126,55} & \multicolumn{2}{|c|}{2,14} & 1,75 & \multicolumn{2}{|c|}{58,99} \\
\hline Thickener drain & 118,7 & \multicolumn{2}{|c|}{157,10} & \multicolumn{2}{|c|}{128,17} & \multicolumn{2}{|c|}{2,17} & 1,77 & \multicolumn{2}{|c|}{0,50} \\
\hline The first rinsing water & 42,7 & \multicolumn{2}{|c|}{70,56} & \multicolumn{2}{|c|}{56,97} & \multicolumn{2}{|c|}{2,71} & 2,19 & & \\
\hline
\end{tabular}


7. Intensive foaming of the washing system. Recycle solution feeding into the process without recycle soda extraction promoted presence of foam. Marked foaming associated with presence of organic impurities in the ore requires organization of special research aimed at finding ways of their output.

\section{Conclusion}

1. The results of proposed technological scheme testing have shown its feasibility in a continuous mode of production and the possibility of iron carbonates extraction by ore grinding on the mother liquor followed by magnetic separation.

2. The output of siderite-depleted concentrate has been identified, the degree of carbonates decomposition at the stage of ore preparation (grinding and magnetic separation) has been determined.

3. Extraction of alumina from bauxite concentrate at leaching stage has been close to the theoretically possible.

4. Satisfactory results on desiliconization, thickening, compressibility and filtration of red mud have been obtained.

5. Analysis of the test data indicates the possibility of improving the performance of the technological scheme by reducing the residence time on the stage of ore preparation and the volume of mother liquor injected with a non-magnetic product in the hydrometallurgical process.

\section{References}

[1] Деревянкин В.А., Чернышов В.Б., Чупраков В.Я., Тринеев В.П. О // Цветные металлы. 1975. № 2. С. 33-35.

[2] Гольдман М.М., Ни Л.П., Ардашова А.И., Турсунбаев Т.Б. // Известия вузов. Цветная металлургия. 1977. № 3. С. 41-44.

[3] Деревянкин В.А., Чернышов В.Б., Поротникова Т.П. // Известия вузов. Цветная металлургия. 1978. № 2. С. 50-53.

[4] Андреев Е.Е., Дубовиков О.А., Николаева Н.В. // Обогащение руд. 2012. № 1. С. 37.

[5] Дубовиков О.А, Наумчик А.Н., Ерёмин Н.И. // Записки Ленинградского горного института: Процессы и оборудование цветной металлургии. Л., 1978. Т. 78. С. 42-44. 